\title{
木構造型メニュー選択システムにおける “深さと広がり”と使いやすさの解析”
}

\section{小松原明哲**}

\begin{abstract}
Usability of tree-structured menu retrieval systems on depth/breadth trade-off is investigated. A user model on menu retrieval behaviour was proposed, which classifies retrieval time into three categories as visual search on a menu, judgement whether the menu item includes the goal, and keying operation. Based on this model, changes of these times were theoretically discussed in relation with learning phenomenon of users, and such tendencies were forecasted that when the menu structure become deeper, the more retrieval time is to be required to reach the goal. Experiments was conducted to examine the change of goal acquisition speed in accordance with learning, and the results which support the forecasts were obtained. In addition, the experiment showed that names of menu items were of importance for usability because names of menu items act as representation of goals in the cognitive ergonomic sense. Besed on these results, several ergonomic guidlines for tree-structured menu retrieval systems were proposed as the conclusion in this study.
\end{abstract}

木構造型メニュー選択システムの階層の深さとメニューの広がりの使いやすさについて, 習熟との 関係において検討した。階層通過の際のユーザの行動をモデル化し, 階層通過時間の内訳を“視覚探 索時間” “判断時間” “オペレーション時間”に分け, これらの各時間の評価指標を情報理論などを参 考に設定したうえで, 習熟とともにこれらがどのように変化するか考察し, 深さと広がりについて解 析的に知見を得た. 次に, この知見を検証するために実験を行った. その結果, 深い階層構造である と探索時間がかかることなどが確認された. また, 上位階層メニュー項目のネーミングは表象として 作用することから，使いやすさに大きな影響を与えることも明らかとなり，これらをもとに使いやす さの観点から木構造型メニュー選択システムの深さと広がりの設計方法について検討した.

(キーワード : 実験認知解析, メニュー選択システム, 学習, ソフトウエアユーザインタフェイス)

\section{1.はじめに}

ワードプロセッサをはじめとする対話型システムに おいては, 機能選択に木構造型メニュー選択システム が用いられることが多い.このシステムでは，多数の 機能を類似した機能どうしに順次階層構造化し，ある 特定の機能を使用したい場合には，各階層のメニュー 項目を順次選択する操作を繰り返し, 最終的に目的と

\footnotetext{
* 平成元年 3 月 16 日受付

** 金沢工業大学 経営工学科
}

Kanazawa Institute of Technology.

\section{する機能に到達する。}

ところで木構造型メニュー選択システムにおいては， 同じ機能項目数を扱うにしても“階層の深さ”と“メ ニューの広がり（1 つの階層に打いて提示されるメ二 ュー項目数)”の設定が，使いやすさに多大な影響を与 えるといわれている8,9). そして階層の深さとメニュー の広がりの間に, 使いやすさの点での分岐点（tradeoff）が存在すると考えられ，いくつかの先駆的研究が なされている。たとえば Miller (1981) ${ }^{6}$, Kiger (1984) ${ }^{3)}$ は, 数種類の木構造型メニュー選択システムにおいて， 探索に要する時間(特定の機能に到達するまでの時間) などを調べ，浅すぎる階層構造も深すぎる階層構造も 
ともに好ましくないことを示している。しかし，これ らの研究では，なぜ浅すぎる・深すぎる階層構造が好 ましくないのかという理由までは十分考察していない， また，ソフトウエアューザインタフェイスの使いやす さについては, ユーザの学習 (習熟) がきわめて大き な影響力をもつことが指摘されているが4,5), 習熟との 関係は従来, 検討されていない。

そこで本研究では, 木構造型メニュー選択システム の階層の深さとメニューの広がりの使いやすさについ て, 習熟との関係において検討を加え, 木構造型メ二 ュー選択システムの設計方法について考察することに した。

\section{2. 研究方法と被験システム}

\section{2-1. 研究方法}

本研究では, 木構造型メニュー選択システムが使い やすいということは，ユーザが主観的に“使いやすい” と感ずるだけではなく，“探索に要する時間が短い”と

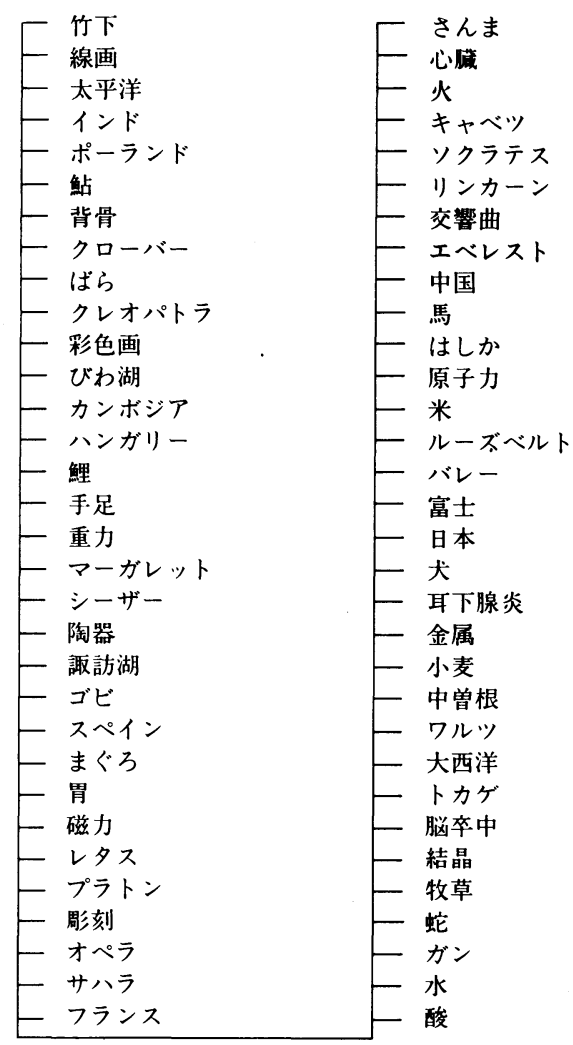

図 $164^{1}$ の階層構造

Fig. 1 Structure of $64^{1}$.
いう探索効率も重要な評価因子であると考え, 使いや すさの評価を “探索に要する時間” “主観評価” の 2 面 から検討することにした。

ところで “探索に要する時間” は, 各階層通過時間 の総計と考えられる。したがって, 階層通過の際の工 一ザ行動をモデル化し，モデルの構造を解析すること で, 効率的側面からの使いやすさについて解析的に評 価できるのではないかと考えられる，そこで本研究で は，まず “探索に要する時間” について解析的知見を 得, その後に実験を行って探索に要する時間, および

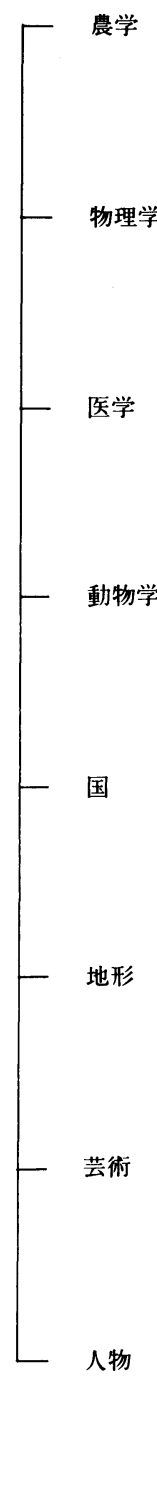

医学

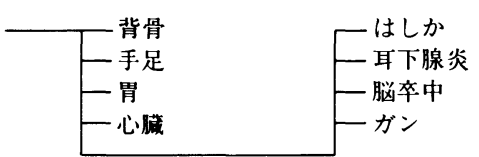

動物学

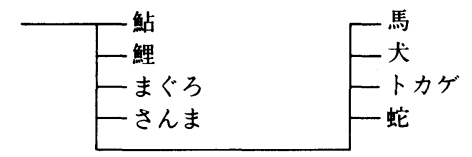

国

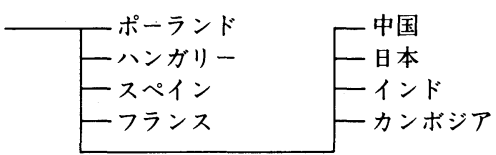

形
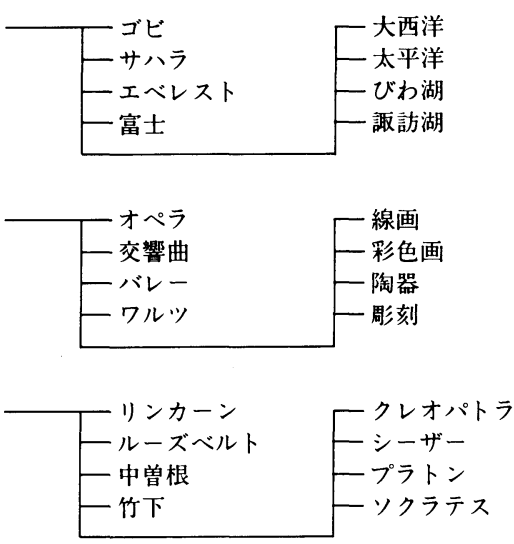

図 282 の階層構造

Fig. 2 Structure of $8^{2}$. 
使いやすさの主観評価を実際に調べ，解析的知見と併 せて使いやすい木構造型メニュー選択システムの設計 方法について考察を行うことにした。

\section{2-2. 被験システム}

本研究では, 検討を具体的に進めていくための被験 木構造型メニュー選択システムとして, Miller $(1981)^{6)}$, 鈴木 $(1988)^{10)}$ を参考にし, 64 の項目から特 定の項目（ターゲットとよぶ）を検索する，以下の 4 種類の木構造型メニュー選択システムをパーソナルコ ンピュータ上に作成した。

（1） $64^{1}$ : 階層数 1.1 つのメニューにおいてのメニ ユ一項目数 64

(2) $8^{2}$ : 階層数 2.1 つのメニューにおいてのメニ ュ一項目数 8

(3) $4^{3}$ : 階層数 3.1 つのメニューにおいてのメニ ユ一項目数 4

(4) $2^{6}$ : 階層数 6.1 つのメニューにおいてのメニ ュー項目数 2

各システムの階層構造を図 1 ～4 に示す.

\section{3. 被験システムの構造解析・考察と 解析結果}

前述のように “探索に要する時間” は, 各階層通過 時間の総計と考えられる。 そこでこの時間は, 基本単 位である“1つの階層を通過する際のユーザ行動”を モデル化することで，解析的に評価できると考えられ る.

メニュー探索に習熟していない段階において，1つ の階層を通過する際のユーザ行動を内観的に考察する と, “メニューの視覚探索(眼球運動とメニュー項目の 読み取り”“ターゲットがどのメニュー項目に属する かの判断” “キーオペレーション”の 3 つの基本行動か ら構成されていると思われる.さらに判断は, ターゲ ットとメニュー項目個々の関連の深さの判断と, それ ら個々の関連の深さを総合的にみて選択すべきメニュ 一項目を決定するという総合判断とから構成されてい ると考えられる。またオペレーションがなされた後, 次のメニュー画面が提示されるまでには，必ず計算機
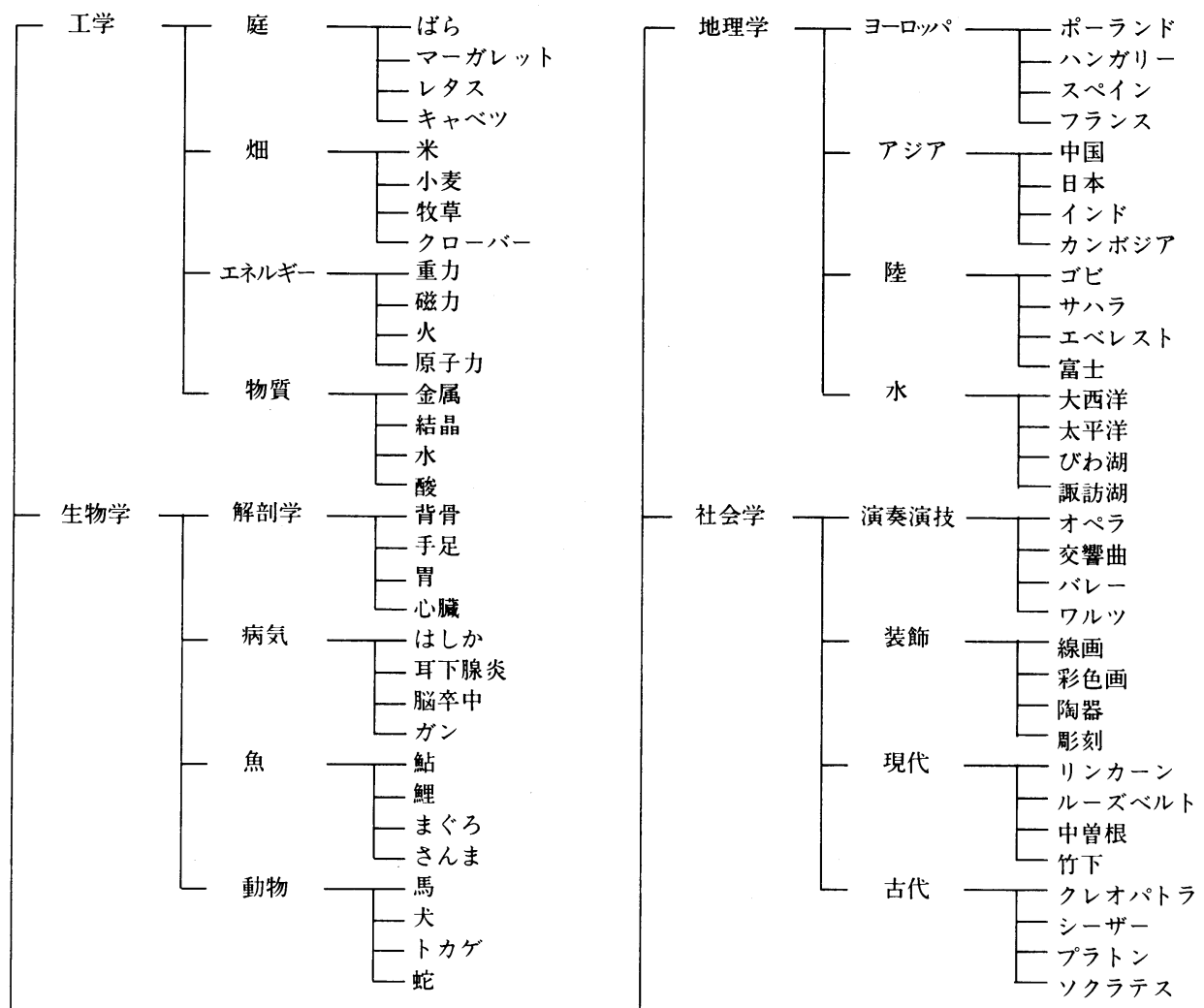

図 $344^{3}$ の階層構造

Fig. 3 Structure of $4^{3}$. 


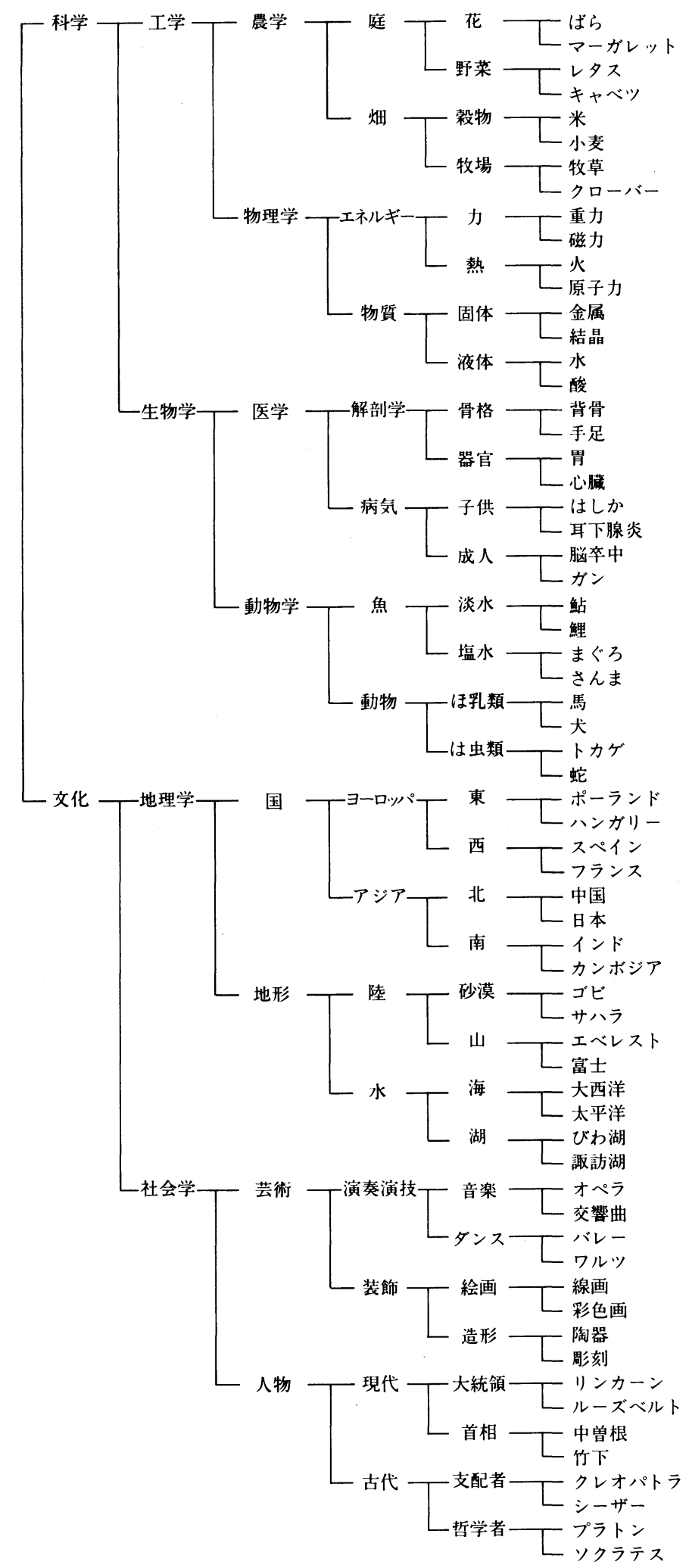

図 $42{ }^{6}$ の階層構造

Fig. 4 Structure of $2^{6}$. 


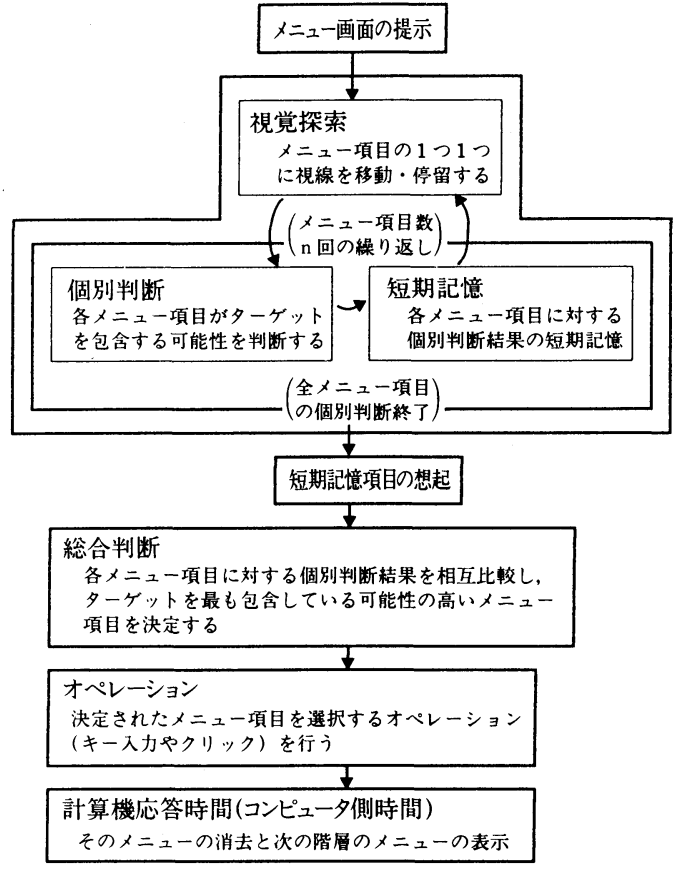

図 5 階層通過の際のユーザ行動モデル

Fig. 5 Model of user behaviour on dealing with a menu.

応答時間が発生する。この状況を図 5 のモデルに示す。

結局 “視覚探索” “判断” “オペレーション”の各段 階において, 階層の深さ・メニューの広がりが利点・ 欠点をもたらし，階層通過時間においての使いやすさ について分岐的関係を生じさせるものと考えられる。 ここで各々の利点・攵点については次のように考察さ れる。

\section{（1）視觉探索}

深い階層構造であると 1 つのメニューにおいて提示 される項目数は少なくてすむ.そこで画面上のメニュ 一の提示領域は狭く，項目を視覚探索する時間も短く てすむという利点がある。この関係は以下に定義され る総出現選択肢数として評価できる．本実験の被験シ ステムに拈いては図 6 の実線のようになり，6419みが 他に比べて好ましくない状態にある，ただし，探索を 繰り返すことで，ターゲットに対して選択すべきメニ ユー項目名やそれが提示される画面上の位置が学習さ れてしまった場合には，視覚探索は行われなくなるの で，使いやすさには無関係となると思われる。

$$
\text { (総出現選択肢数) }=\sum_{\mathrm{i}=1}^{\mathrm{n}}(\mathrm{mi})
$$

$\mathrm{mi}$ ：第 $\mathrm{i}$ 階層におけるメニュー項目数. $\mathrm{n}$ ：階層数。

\section{(2) 判 断}

階層が深くなるにつれて, より上位の階層のメニュ 一項目名は，多くのターゲットレベルの項目を包括す ることから，特定のターゲットに対しては抽象的・曖 昧にならざるをえず，これがメニュー項目の選択にお いて戸惑いをもたらすのではないかと考えられる。こ の曖昧さは，1つのメニュー画面において提示される メニュー項目数を選択の可能性として考えればエント ロピーで，メニュー項目とターゲットの意味的関連の 深さという質的側面を考えれば，後述する表象関係で 理解できる。

エントロピーについては次のように考えられる．各 階層のメニューにおいて，各メニュー項目が等確率で 選択されると仮定すると，ターゲットレベルのメニュ 一項目のもつ曖昧さは，各階層のメニューにおいての 情報理論でいうエントロピーの総和で表現できる ${ }^{2,7)}$.

深く階層構造化すると，エントロピーは大きくなる が，エントロピーが大きいということは，それだけ曖 昧であるということであり，判断時間の長期化を示唆 するので好ましくない.ただし探索の繰り返しととも にターダットとメニュー項目との関係の学習が完成し ていけば，エントロピーの大きさは使いやすさには無 関係になると思われる。しかし，各階層ごとにターゲ ットに対して選択すべきメニュー項目を学習しなくて はならないわけであるから，深く階層構造化するとそ れだけ学習量が増えることから，エントロピーが大き いと習熟が阻害されると思われ，好ましくないと考え られる。

$$
(\text { エントロピー })=\sum_{\mathrm{i}=1}^{\mathrm{n}}\left(\log _{2}(\mathrm{mi}+1)\right)
$$

$\mathrm{mi}$ : 第 $\mathrm{i}$ 階層においてのメニュー項目数.なお, $(\mathrm{mi}+1)$ とするのは, 今回は後述するように誤ったメ ニューを選んだ場合の取り消し操作を許すためである。 $\mathrm{n}$ : 階層数.

ここで本論文での 4 種類の実験構造においてエント ロピーを求めると, 図 6 の点線のようになり， $2{ }^{6}$ だけ が高いエントロピーを示している。

\section{(3) オペレーション}

木構造型メニュー選択システムにおいては, 階層の 通過に際して必ず 1 回はキー操作（クリック）をしな くてはならず，このとき必ずオぺレーション時間と計 算機応答時間が発生する。そこで深く階層構造化する と，ターゲットに到達するまでの探索時間が比例的に かかってしまう。これは習熟とは無関係で，階層通過 回数（階層数そのもの）として評価できる。ここで被 験システムについてみると図 6 の破線のようになる. 


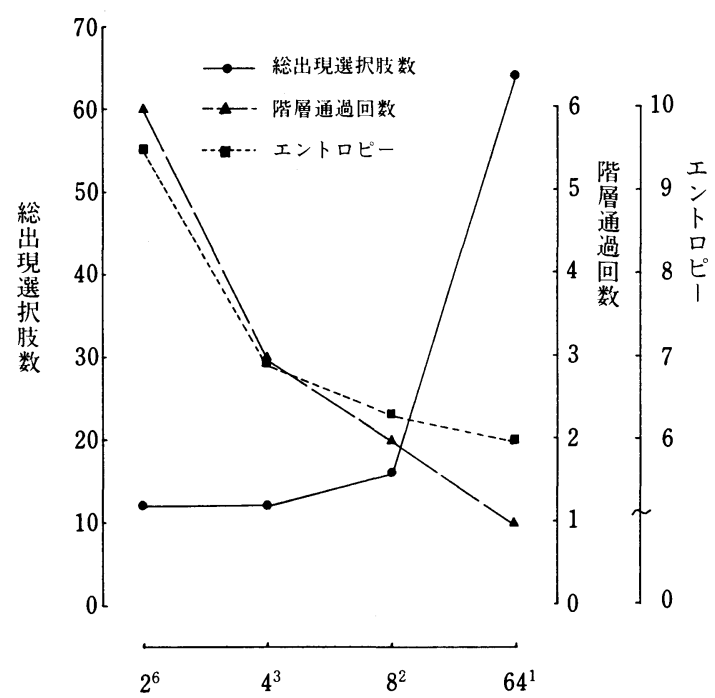

図 6 各被験システムの解析結果

Fig. 6 Characteristics obtained by theoretical analysis on each menu retrieval system in this study.

上述した 3 つの観点をまとめると, 習熟の初期段階 においては $64^{1}$ は出現選択肢数の点で， $2^{6}$ は階層通過 回数とエントロピーの点で，それぞれ好ましくない. 3 つの指標に極端にわるいものがないのは $8^{2}$ の場合 であり，最も短い探索時間が期待される。これらの考 察は前述の Miller $(1981)^{6)}$, Kiger $(1984)^{3)}$ と一致す る．また探索を繰り返していくと，総出現選択肢数・ エントロピーの効果は少なくなってくることが期待で きるので, 習熟につれて階層通過回数の点で $2^{6}$ のが

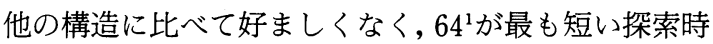
間を示すことが期待される。一方，習熟のしやすさに ついては, エントロピーが極端に大きい $2{ }^{6}$ は習熟が遅 いと思われる。

\section{4. 被験システムの習熟を調べる実験}

前項で述べた構造解析からの知見が実際に成立する か検討し，また使いやすさの主観評価との関係を検討 することを目的に, 習熟過程を調べる実験と解析を行 った.

\section{4-1. 方 法}

\section{（1） 習熟実験の方法}

次の実験方法によって，4 種類の被験システムを比 較した。

まずCRT 上に探索すべきターゲットを 1 つ提示し,
被験者に確認させ，確認キーを押させる，次に最初の メニュー（第 1 階層メニュー）を提示する．各メニュ 一項目には番号がつけられているので，被験者は夕一 ゲットが属すると思われるメニュー項目の番号を，テ ンキーから入力する．以下，順次この操作を繰り返し， 最終的にターゲットに到達する。なお，誤ったメニュ 一項目を選択した場合には，0を入力することで前の 階層メニューに戻れるようにした。

予備実験の結果，階層が深まると探索中にターゲッ 卜を忘れてしまうことが観察されたので, $64^{1}$ を除く各 被験システムでは，メニュー画面の上隅にターゲット を常時提示しておくようにした。

実験は各被験システムでの探索を連続 100 回, 被験 者に課し，このとき以下の測定を行った。

(1) ターゲットが提示されてから, 探索が完全に終 了するまでの探索時間. 誤った選択をした際に前 の階層に戻る場合の時間も含む.

（2）各階層間の通過時間。すなわち各メニュー画面 が提示されてからメニュー項目の選択キー入力が あるまでの時間。

（3）各ターゲットにおいての探索経路.すなわち提 示されたターゲットと, 各階層で選択されたメニ ュー項目番号.

（4）使いやすさ評価. 100 回の探索の 10 回ごとに, 使いやすさの程度を“やりやすい一やりにくい”

の 7 段階評定尺度によって評価させる。

なお，(1)〜(3)は実験ソフト上で自動的に計測するよ うにした，分析は，(1)，(4)は習熟との関係をみるため に時系列的に解析した。(2)，(3)は後述する質的解析に おいて分析に供した。

ここで提示するターゲットは, 100 回の探索の繰り 返しの特定の時期に特定の探索経路の探索が連続して 出現することなく，全探索経路が偏りなく探索される ように, 64 項目のうち 32 項目をあらかじめ選び, 100 回の繰り返しの前期・中期・後期に, それぞれほぼ 1 回ずつ出現するようにした。なお各期においては，32 項目の出現順序はランダマイズした。被験者は男子大 学生 10 名とし, 実験はパーソナルコンピュータ (NEC PC 9801 VX 41, KD 871 CRT) を用い, 暗幕で周囲を 囲った静かな環境下で行った。 また，4種類の被験シ ステムの実験順序は被験者内でランダマイズし，各実 験間には十分な休息をとった。

\section{（2）階層粠造の質的解析の方法}

前述したエントロピーは，上位階層のメニュー項目 とターゲットとの間の質的（意味的）関係の強さには 注目していない．しかし意味的側面を考えると，上位 階層のメニュー項目は下位階層のメニュー項目やター 
ゲットの, 認知科学でいう表象であるといえる1).ここ で表象が包含する項目を包括的に適当に表していない と, ターゲットの探索において正しく表象が選択され なくなってしまい, 探索時に戸惑いや誤った探索がな されて探索時間が長期化し, また学習の進行が阻害さ れると考えられる。すなわち, 木構造型のメニュー探 索システムを習熟的に評価する際には, 質的側面を考 えないエントロピーや単純な被験システム間の習熟比 較だけではなく, ターゲットとそれを含む表象（各階 層のメニュー項目名）との意味的関係の強弱と習熟と の解析もきわめて重要になると考えられる。 そこで本 研究では, ターゲットと表象としてのメニュー項目の 間の意味的関係の強さと習熟傾向との関係についても 以下のように解析した。

まず被験者と同一母集団に属する男子大学生 40 名 に対して, 実験で用いた 32 個のターゲットとすべての メニュー項目名との間の関係度の深さを, 10 点満点で アンケート形式で主観的につけてもらった。次に特異 な回答をした回答者がいないことを確認したうえで, 各階層のメニューにおいて次式を定義し, ターゲット とそれに対して選択すべき正しいメニュー項目との意 味的関連度を求めた。

$$
\text { (意味的関連度 })=\mathrm{A}+\left(\sum_{\mathrm{i}=1}^{\mathrm{n}}(\mathrm{A}-\mathrm{Bi})\right) / \mathrm{n}
$$

A：ターゲットに対して選択すべきメニュー項目と ターゲットとの間の関係の深さの平均評点. B : 同じ く選択すべきでないメニュー項目とターゲットとの間 の関係の深さの平均評点. $\mathrm{n}: \mathrm{B}$ の項目数.

ここでカッコ内は選択すべきメニュー項目と選択す べきでないメニュー項目との意味的偏差を考慮してい る.その理由は，たとえばいかにターゲットに対して 選択すべきメニュー項目が適切につけられていたとし ても，選択すべきでないメニュー項目もターゲットの 包含を暗示するようにつけられて同時に提示されてい るとするなら, 被験者はどちらの項目を選択すべきか 躊躇してしまうからである。すなわち，単にターゲッ トと選択すべきメニュー項目との関係をみるだけでは なく, 同時に提示される他の項目の影響を加味する必 要があると考えられるからである.

以上の手続きによって, ターゲットと選択すべきメ ニュー項目との意味的関連度を一つひとつ求めたうえ で, 各被験システムごとに, 全ターゲットについて意 味関連度の最大值と最小值を調べ，その範囲を三等分 し, 意味的関連度の強・中・弱ごとに, そのメニュー 項目が提示されている階層の通過時間を求め, 100 回 の繰り返しの 10 回ごとに平均階層通過時間を求めて 習熟傾向を調べた。

\section{4-2. 結果および考察}

\section{（1）習熟傾向}

各被験者において各被験システムの 100 回の繰り返 しの 10 回ごとに平均探索時間を求め, 指数回帰した. 各被験者について習熟度の大きい順に被験システムに 順位をつけたところ, 10 人の被験者の習熟傾向が有意 に一致したので, 100 回の繰り返しの 10 回ごとに全被 験者の平均探索時間を求め,さらに指数回帰した。結 果を図 7 に示す. 深く階層構造化すると, 習熟の全過 程において順次, 探索時間も長期化し，特に $2^{6}$ の場合 の探索時間が他に比べてきわめて長い.これは構造解 析で述べたように, $2{ }^{6}$ は階層通過回数が 6 回と他より 多いためであると思われる。また今回の実験では, 計 算機応答時間は約 0.1 秒であったが, 計算機応答時間 が延びれば，そのぶん被験システム間の探索時間の開 きはより大きくなると考えられる。

一方, 前述のように習熟の初期においては $8{ }^{2} か ゙$ 最も 短い探索時間を示すことが期待されたが, 実験結果で は $64^{1}$ のほうが短かった. 82 では階層通過回数・エント ロピーが $64^{1}$ より若干大きく,これが視覚探索時間よ りも大きい影響を与えたためと考えられる。

習熟傾向については, 構造解析で述べたように, 階 層が深まるにつれエントロピーが増大するため, 深く 階層構造化するにつれて習熟傾向が弱まることが予想 されたが, 明確な傾向は示されなかった。

\section{（2）使いやすさの評価}

使いやすさの評価傾向を図 8 に示す. 実験の進行と ともに, 各階層とも評価は良好化している，ただし， $4^{3} \cdot 8^{2}$ の評価に比べて, $2^{6} ・ 64^{1}$ は実験の全期間にお いて評価がわるい，すなわち，浅い階層構造・深い階 層構造ともに好まれず, $64^{1}$ が最もよいという探索時間

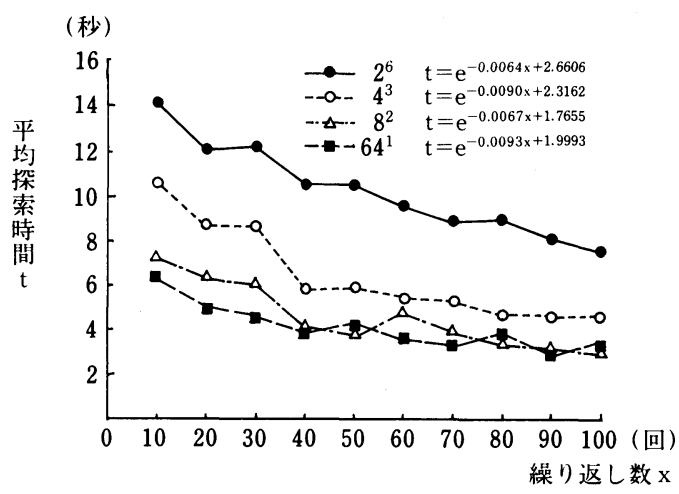

図 7 各階層の探索の学習傾向

Fig. 7 Learning tendency of menu retrieval on each menu retrieval system in this study. 

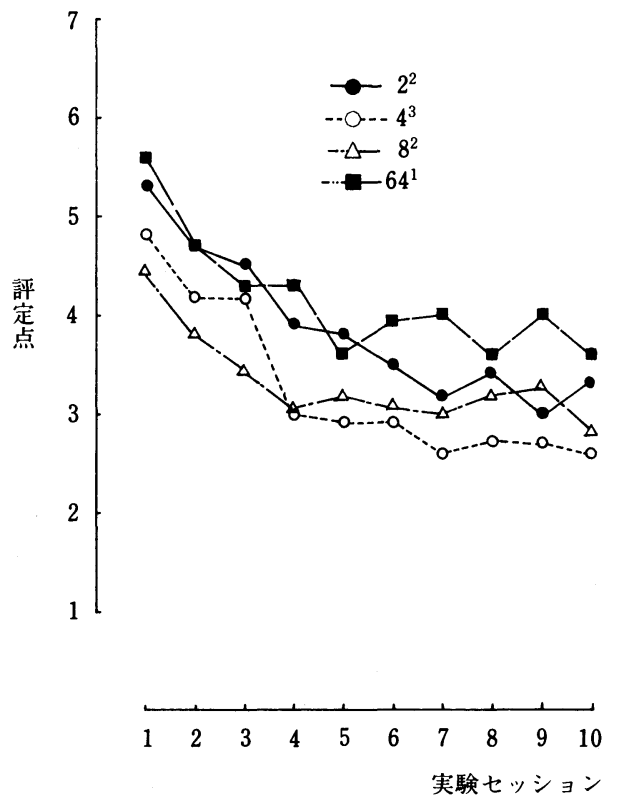

図 8 “やりやすい一やりにくい”の評定の 変化傾向

Fig. 8 Change of subjective evaluation of retrieval easiness on each menu retrieval system in this study.

の傾向とは一致しない. $64^{1}$ は画面上いっぱいにメニュ 一が提示されることなどを考えると, 使いやすさの評 価には時間的側面だけではなく, メニュー画面の大き さをはじめ，他の要因が影響するものと思われる。

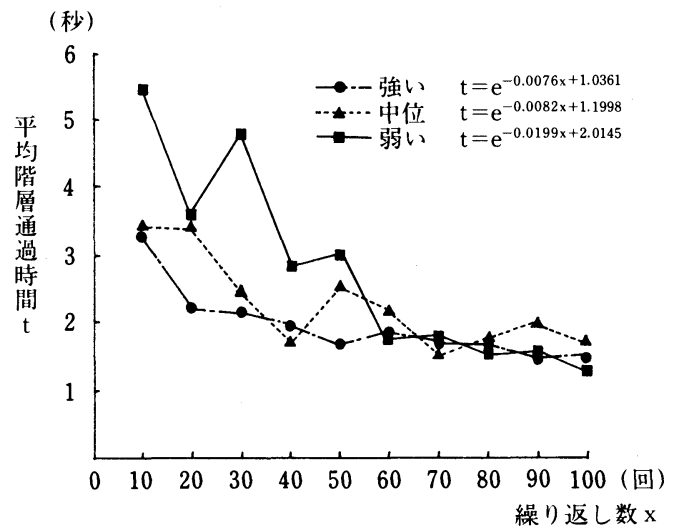

図 $98{ }^{2}$ の場合の意味関連度別階層通過時間の変化傾向

Fig. 9 Change of required time to deal with one menu on $8^{2}$ retrieval system (respective results of each group of meaning-relation tightness between menu names and target items).

\section{（3）表象と習熟傾向}

階層をなさない 641 を除き, 各被験システムごとに 前述の手続きによって意味関連度別習熟曲線を求め, さらに指数回帰した．図 9〜11に結果を示す.

各被験システムともに, 意味関連度が弱いと繰り返 しの初期において階層通過時間がより長くかかること がわかる。しかし習熟傾向は大きく，ターゲットに対 して適切とはいえないメニュー項目名であったり， あ るいは同時に意味関連度の高いメニュー項目名が提示 されても, 繰り返していくうちにターゲットに対して 正しいメニュー項目の選択が学習されていくことがわ かる.

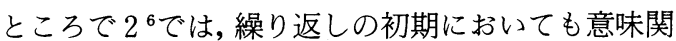
連度による階層通過時間の違いは大きくはなく, 階層 通過時間は短い。これは次のように考えられる，すな わち，階層が深まるとターゲットに対して選択すべき メニュー項目名も暧昧にならざるをえず，意味関連度 の最大值と最小值の幅が小さくなってしまったためと 思われる.ただし $2^{6}$ では, 各メニューにおいての選択 は二者択一であるので，2つのメニュー項目のもつ意 味関連度のわずかな違いをもとにして素早く選択の決 定がなされるため，階層通過時間は短くてすんだもの と思われる。

\section{5. まとめ}

本研究では木構造型メニュー選択システムの階層の 深さとメニューの広がりについての使いやすさの分岐 について, 構造解析とそこから導かれる知見の検討を

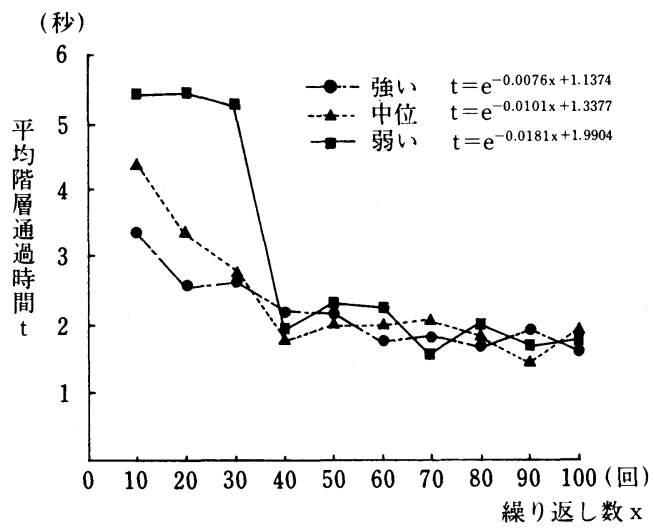

図 $104{ }^{3}$ の場合の意味関連度別階層通過時間の変化傾向

Fig. 10 Change of required time to deal with one menu on $4^{3}$ retrieval system (respective results of each group of meaning-relation tightness between menu names and target items). 
実験によって行った。また，メニュー項目をターゲッ トに対する表象として捉え, 意味的関連度と習熟との 関係を検討した，結果は以下のようにまとめられる。

（1）木構造型メニュー選択システムを使用するュー ザの探索行動をモデル化し，それに従って“視覚 探索”“判断” “オペレーション”の 3 観点から, 被験システムを解析・評価した。その結果, 探索 の繰り返しの初期の段階においては，3点のいず れもが探索時間に影響を与えると考えられたが, 習熟の進行とともに“オペレーション”のみが探 索時間に影響を与えると考えられた。実験結果に よると， $64^{1} \cdot 8^{2}$ また $4^{3}$ は習熟の進行とともにほ ぼ同じ探索時間化してくるのに対して， $2^{6}$ は探索 時間は他に比べて常に長く,この仮説はおおおね 正しいものと思われた。

(2）習熟のしやすさについては，エントロピーの大 きさがこれを表すものと考えられ，エントロピー の大きい $2{ }^{6}$ が習熟しにくいと予想されたが, 実験 ではあまり明確な傾向は示されなかった.

（3）使いやすさの評価についてみると，浅い・深い 構造のシステムは好まれず, 習熟の全過程におい て $2 \sim 3$ 階層程度の深さが常に好まれた。この傾 向は, 浅い階層構造のほうが探索時間が短いとい う時間的結果とは一致しない。これは探索時間以 外の要因が影響するものと思われるが，今回の研 究ではつまびらかでないので, 今後の検討課題で ある。

（4）ターゲットに対する表象が適切についていない と，探索に時間がかかってしまうことが予想され， 実験でも支持された。ただし，探索の繰り返しと

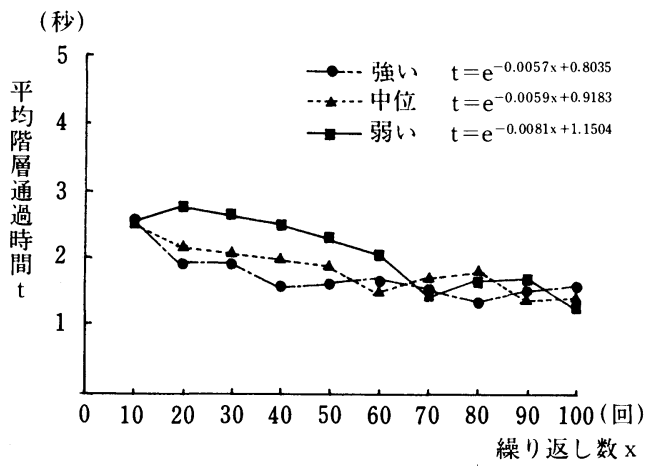

図 $112{ }^{6}$ の場合の意味関連度別階層通過時間の変化傾向

Fig. 11 Change of required time to deal with one menu on $2^{6}$ retrieval system (respective results of each group of meaning-relation tightness between menu names and target items).
ともにターゲット・表象関係が学習されてくると 思われ，最終的には意味的関連性は探索時間に影

響を与えなかった。

以上の結果をもとに，ワードプロセッサなどの対話 型システムにおける木構造型メニュー選択システムの “階層の深さ”と“メニューの広がり”についての設 定の方法を, 習熟との関係において考察すると, 以下 のように考えられる。

（1）対象ユーザが初心者やノビスユーザであって習 熟が見込まれない場合や，ターゲットがたまにし か使われないような機能で探索経路の学習が期待 できない場合は, “視覚探索” “判断” “オペレーシ ヨン”ともに探索時間に影響を与えるので，これ ら 3 者を総合化してユーザに対する負担が小さい 階層構造がよい.すなわち浅くも深くもない階層 構造が好ましい.

（2）対象ユーザが熟練者である場合や，ターゲット が頻繁に使用される機能で探索経路の学習が期待 できる場合には, “視覚探索” “判断” 時間は短縮 化が期待でき，探索時間は “オペレーション” 時 間のみの影響を受けることなる。そこで探索時間 に関しては浅い階層構造のほうが好ましい。

（3）ターゲットと表象との関係は，探索時間にきわ めて強い影響を与えることが確認された。したが って，メニュー項目のネーミングは包括する機能 項目を適切に連想させるよう，慎重に行わなくて はならない.

以上の結論をまとめると，木構造型メニュー選択シ ステムの設計においては, “視覚探索” “判断” “オペレ ーション”の 3 つの観点と “表象関係”を学習（習熟） の関係下で重視する必要があり，3つの観点について は“総出現選択肢数” “エントロピー” “階層通過回数” が評価指標となると考えられた。また，使いやすさの 主観評価は探索効率と必ずしも一致せず，さらに詳細 な検討が必要であるいえよう。

\section{謝 辞}

本研究にご教示いただいた日本電気(侏鈴木昭一(前) CID 室長, 早稲田大学理工学部横溝克巳教授, 同院生 （当時）鈴木敏幸氏，金沢工業大学学生（当時）西野 伸一君にお礼申し上げます。

\section{参考文献}

1）安西祐一郎：認知科学と人工知能，37〜 39 , 共 立出版, 1987 .

2) Card, S. K., Moran, T. P., Newell, A. : The Psychology of Human-Computer Interaction, 
71 76, Lawrence Erlbaum Asso. Pub., 1983.

3) Kiger, J. I. : The Depth/Breadth Trade-off in the Design of Menu-driven User Interface, Int. J. Man-Machine Studies, 20, 201 213, 1984.

4）小松原明哲, 中島徳夫, 横溝克巳: 学習過程か らみた日本語ワードプロセッサの “とりつきやす さ”について, 人間工学, 23(1), 25〜33, 1987.

5) Komatsubara, A., Yokomizo, Y. : Evaluation of Japanese Word Processors on Learning Process and Cognitive Ergonomics, Man-Computer Interaction Research MACINTER, Vol. 2 (F. Klix, et al. ed.), Elsevier Science Pub., 479 498, 1989.

6) Miller, D. P. : The Depth/Breadth Trade-off in Hierarchical Computer Menus, Proc. of the 25 th Human Factors Society Annual Meeting, 296 300, 1981.

7）小沢一雅：情報理論の基礎，22～23，国民科学 社, 1980 .

8) Rubin, T. : User Interface Design for Computer Systems, 54 58, Ellis Horwood Ltd., 1988.

9) Shneiderman, B. : Designing the User Interface, 97 104, Addison-Wesley Pub., 1986.

10）鈴木敏幸：日本語ワードプロセッサの人間工学 的研究, 早稲田大学大学院理工学研究科修士論文, $120 \sim 122,1988$. 